\title{
DESIGN AND IMPLEMENTATION OF SOFTWARE SUPPORT FOR BIOMETRICS LABORATORY COURSES
}

\author{
HAMBALÍK Alexander - MARÁK Pavol, SR
}

\begin{abstract}
In this paper we decided to outline the most critical stages and design procedures of software support intended mainly for laboratory lessons of the Biometrics course. At the authors' institution, this course is mandatory since 2015 according to the new accreditation. Thanks to cooperation with the Institute of Forensic Science in Bratislava we gained sufficient experience in the field of analysis and utilization of biometric traits. However, this experience does not guarantee solving of all problems linked to teaching biometrics courses. Hence, we decided to design the software support using our present research results and make use of our experience in development of application and computer network software to improve the quality of biometrics-related education. The software is primarily intended for universities focusing on technology area. Nevertheless, it can be also used in training forensic experts as the software provides many possibilities to analyze properties of fingerprint patterns. In near future, after addition of necessary modules, it will be possible to deploy it in education of experts from various fields of biometrics and digital image authenticity verification.
\end{abstract}

Key words: biometrics, fingerprint recognition, deep pattern analysis, software support for courses, software design

\section{NÁVRH A REALIZÁCIA SOFTVÉROVEJ PODPORY CVIČENÍ PREDMETU BIOMETRIA}

\section{Resumé}

V našom príspevku sme sa rozhodli načrtnút' najdôležitejšie fázy a kroky návrhu a realizácie softvérovej podpory určeného hlavne pre laboratóriá predmetu Cvičenia z biometrie. Na našom pracovisku podl'a novej akreditácie sa tento predmet vyučuje povinne od roku 2015. Vd'aka spolupráce s Kriminalistickým a expertíznym ústavom policajného zboru v Bratislave máme už dlhšie obdobie skúsenosti z analýzy a využivania biometrických znakov na vyššej úrovni. To ale neznamená, že tieto skúsenosti už všetky problémy, ktoré sú spojené s výučbou predmetu Biometria, dovolili vyriešit'. Preto sme sa rozhodli navrhnút' softvérovú podporu z vlastného vývoja a využit' $v$ rámci cvičení všetky naše doterajšie niekol'koročné skúseností z tvorby aplikačného a siet'ového softvéru pre biometriu. Systém je prioritne navrhovaný pre účely vysokých škôl technického zamerania, ale vel'mi dobre by sa dal využit' v rámci prípravy kriminalistických a iných expertov, kde sa zaoberá s vlastnost’ami daktyloskopických stôp. V budúcnosti, po doplnení potrebných modulov, bude možné ho nasadit' aj $\mathrm{v}$ príprave expertov $\mathrm{z}$ iných oblasti biometrie a z rozpoznávania originality (nezmenenosti) digitálnych obrazov.

Kl'účové slová: biometria, daktyloskopia, hĺbková analýza vzorov, softvérová podpora cvičení, návrh vlastného softvéru

\section{Introduction}

Until recently, biometric features and their sensing, processing and examination have been almost exclusive domain of forensic experts. Today, situation has changed dramatically. We deal with these tasks very often in connection with designing hardware or software parts of various commercial devices. They are a part of authentication processes of embedded devices or daily used, 
mostly mobile gadgets. For a secure authentication, it is sometimes not enough to use just a password. In spite of that, this is the prevalent form of authentication in everyday life. We can face this problem using biometric traits with the rapid price drops of sensors on higher security level. By using them, besides higher security, it provides user with higher service comfort with small risk of accidental or intentional disclosure of access privileges. At present, especially fingerprints are dominant in this area. Except specialized institutions, primarily schools should train experts of required level in order to cover present growing requirements including activities from design to day-to-day usage of biometric data.

Primary aim of our system is area of high school education focusing on technologies. However, it is supposed to be of very good use during training of forensic or other experts helping them study biometric patterns and their properties. In near future, after addition of necessary modules it can help experts from different subfields of biometrics and digital image authenticity recognition.

\section{Conceptual model for software support system}

During design stage we kept in mind requirements of Biometrics course. Besides them, we took into consideration our and published long-term experience in biometric software design. They concerned software organization into function blocks, choice of programming language in given operating system and its library support and many other factors. We did our best to present the entire design in a complex manner.

According to valid course curriculum, laboratory classes are divided into these two parts:

- Dactyloscopy (fingerprints, palmprints and footprints)

- Authentication using different biometric features (face, retina, iris, etc.).

In the first stage of development we focused on dactyloscopy. In this area, deep analysis is supported by practically no commercial and non-commercial products. It caused by difficulty of automated recognition of fingerprint features, so-called minutiae. Their typology and size definition is not unified even for experts. Moreover, for purposes of identification, complex deep analysis of ridge skin print is not necessary. For standard purposes, it is sufficient to determine locations of predefined number of ridge endings and ridge bifurcations and their mutual spatial relationship. Software support for recognition of features other than fingerprints will be implemented in the next stage of development by adding new modules to the system. In addition to these modules, we plan to incorporate support for digital image authenticity recognition with no need for an original image ("negative").

Standard criteria of the first stage of development were as follows:

- System must be designed to have application and network support for different platforms of most widely used operating systems.

- Open source products will be used during development.

- Every student can access the system during laboratory classes, but also during whole semester in school and out-of-school locations.

- The system must support the education and individual study as much as possible.

- It must be module-oriented with easy further module implementation.

- User interface must be intuitive and uniform, it must provide batch data processing, it must support many formats and image resolutions.

- It must enable deep fingerprint property analysis using various methods, both locally and through the network. 


\section{Block diagram of fingerprint processing}

We used our experience in constructing a block diagram of fingerprint processing. Majority of procedures employs image preprocessing comprising direct image capturing, storing in digital form, background segmentation, color normalization, adaptive enhancement using filters such as Gabor filters or spurious image structure deletion. All this is followed by thresholding (results in black and white image), ridge line thinning (reducing ridge width to 1 pixel), minutiae extraction (minutiae type, direction and location determination). At the final stage, results are stored locally or to a secure server and may be statistically evaluated if necessary.

Tab. 1 - Complete list of minutiae features

\begin{tabular}{|c|c|c|c|}
\hline Minutiae title & Sample image & $\begin{array}{c}\text { Frequency of } \\
\text { occurrence in \% in } \\
\text { Slovakia }\end{array}$ & Description \\
\hline Ridge bifurcation & B & 43,02 & Ridge line is split into two parts. \\
\hline Ridge ending & & 35,94 & Natural ridge line termination. \\
\hline Fragment & & 6,94 & $\begin{array}{c}\text { Short ridge with length in range from } 2 \text { to } 10 \\
\text { sweat pores. }\end{array}$ \\
\hline Lake/Eye & & 3,67 & $\begin{array}{l}\text { Ridge is split and reconnected in range of } \\
\text { maximum } 10 \text { sweat pores. }\end{array}$ \\
\hline Overlap & & 3,29 & $\begin{array}{l}\text { Two overlapping ridge lines up to the length of } \\
10 \text { sweat pores. }\end{array}$ \\
\hline Point & & 2,84 & $\begin{array}{l}\text { Very short ridge line containing maximum } 1 \\
\text { sweat pore. }\end{array}$ \\
\hline Break & & 2,76 & $\begin{array}{l}\text { Opposite endings separated by the gap of } \\
\text { maximum } 5 \text { sweat pores. }\end{array}$ \\
\hline Bridge & & 0,84 & $\begin{array}{c}\text { Very short ridge line connecting two parallel } \\
\text { ridges. }\end{array}$ \\
\hline Crossbar & & 0,78 & $\begin{array}{l}\text { Two endings with one line crossing from one } \\
\text { side to another. }\end{array}$ \\
\hline Opposite bifurcations & & 0,17 & $\begin{array}{l}\text { Two opposite ridge bifurcations originating } \\
\text { from the same point. }\end{array}$ \\
\hline Dock & & 0,13 & $\begin{array}{l}\text { Ridge ending parked between two opposite } \\
\text { endings with overlap of maximum } 10 \text { pores. }\end{array}$ \\
\hline Trifurcation & & 0,07 & Ridge line is split into three branches. \\
\hline Spike/Hook & & Not available & $\begin{array}{l}\text { Tiny ridge protuberance with length of } \\
\text { maximum } 10 \text { sweat pores. }\end{array}$ \\
\hline Return & & Not available & $\begin{array}{l}\text { Ridge line return that is not a part of fingerprint } \\
\text { core. }\end{array}$ \\
\hline
\end{tabular}

When recognizing global patterns (Level-1 features) and minutiae (Level-2 features), pixel properties (e.g. Crossing Number technique) or artificial intelligence approaches (e.g. neural networks) are used most frequently. Our system recognizes more complex Level-2 data using its own algorithms. There are the most common minutiae types in Fig. 1. Blue frames denote minutiae that our system was capable of detecting at the beginning of development. There is a complete table of all known minutiae types along with their descriptions in Tab. 1. 


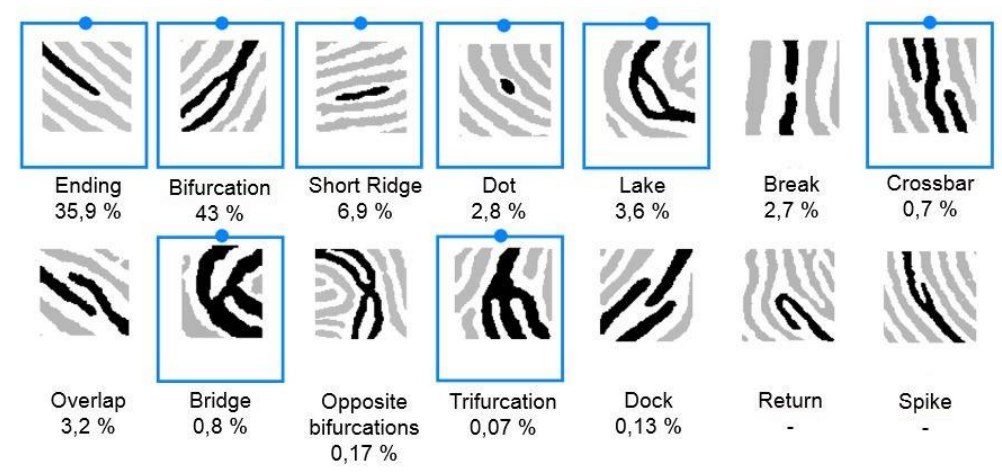

Fig. 1 - Taxonomy of most frequent minutiae types and their frequency in fingerprints of Slovak population (Marák and Hambalik, 2014, p. 4)

Today's system version is more advanced, but it also has limits of usability. It is able to recognize basically all listed types of minutiae, but so far recognition accuracy differs from type to type. The best way according to our experiments to recognize Level-1 features is to use neural networks. Level-1 features are global patterns (classified into 5 or 6 groups, e.g. left or right loop, arch, tented arch, whorl and twin loop). We cannot determine one's identity only by Level-1 patterns, but if recognized correctly they may reduce time needed to search vast databases. Level-3 details (mainly sweat pores) are not handled by our system in the current version. It is not a significant limitation as these details are used not too much in automated recognition systems of nowadays. This is partly caused by quality of captured biometric data and its subsequent processing. It is supposed their importance in forensic and civil applications will grow in near future. Therefore it will be necessary to develop new algorithms for their reliable recognition.

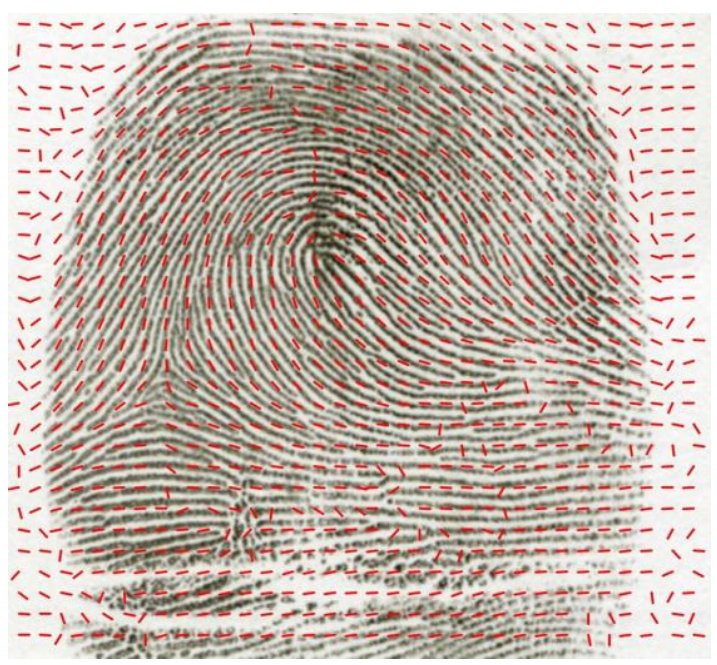

Fig. 2 - Sample fingerprint image with left loop pattern and orientation map computed by our software application (Grznár, 2015)

There are also methods that do not incorporate image preprocessing thus not introducing additional deficiencies into fingerprints (do not generate artificial patterns or do not eliminate real patterns). At present our system supports two such methods, one based on ridge line contour tracking and the second based on well-known FingerCode method. 


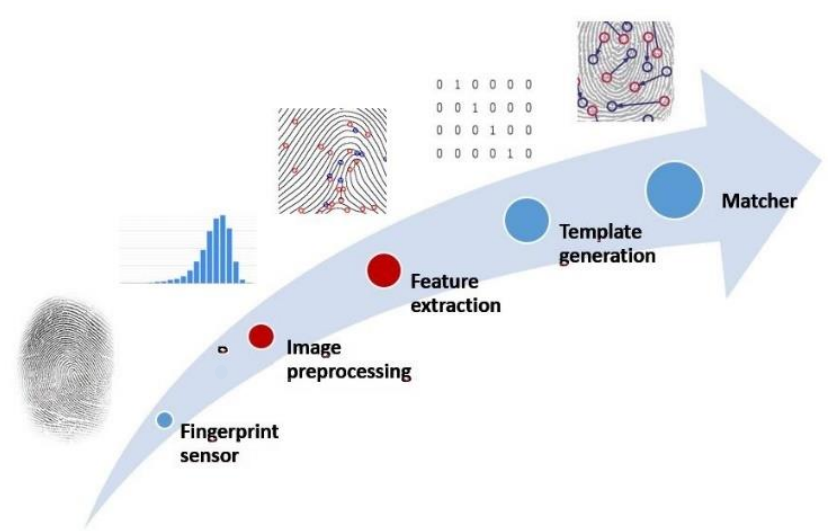

Fig. 3 - Standard fingerprint processing workflow (Marák and Hambalik, 2014, p. 4)

During our work we found out that to achieve acceptable minutiae extraction accuracy by neural networks we need to collect quite a large number of customized training sample images of minutiae directly from real fingerprint pattern. Their automated marking and extraction from the image would be too difficult. For this purpose, we developed a software tool that allows user to manually highlight a customizable block in fingerprint and it automatically cuts out the corresponding image area and saves it in automatically created folder. This way we are able to collect two types of minutiae: ridge ending and bifurcation.

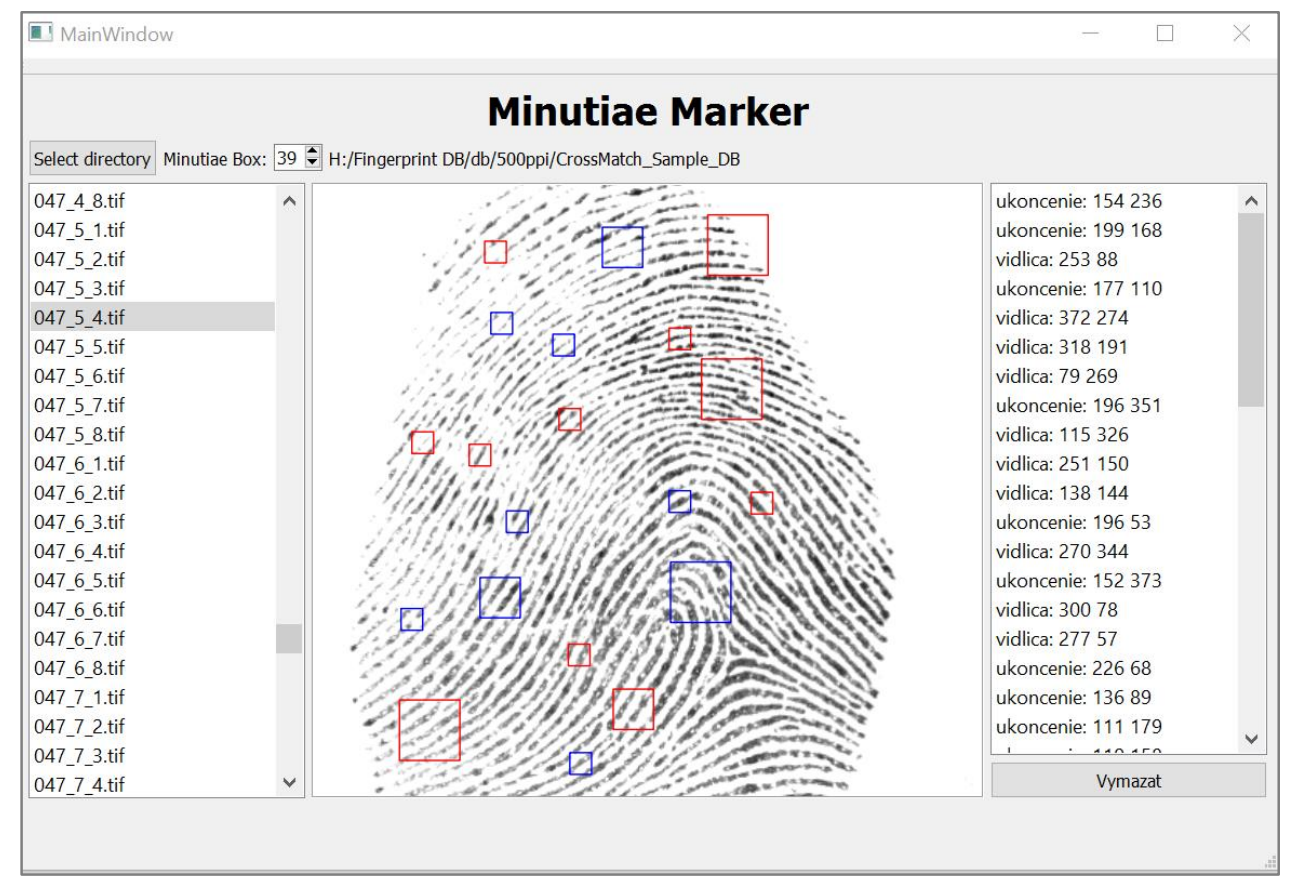

Fig. 4 - Our single-purpose application for manual extraction of minutiae for neural network training (red blocks - bifurcations, blue blocks - endings)

Lately, we dedicated most of time to server support of our system to scale our computing needs. Usability of the system in batch mode of processing heavily depends on its quality. One of the first server-based fingerprint processing applications we developed uses neural network to extract minutiae. It is accessible through a website user interface. Details can be seen in Fig. 5. 


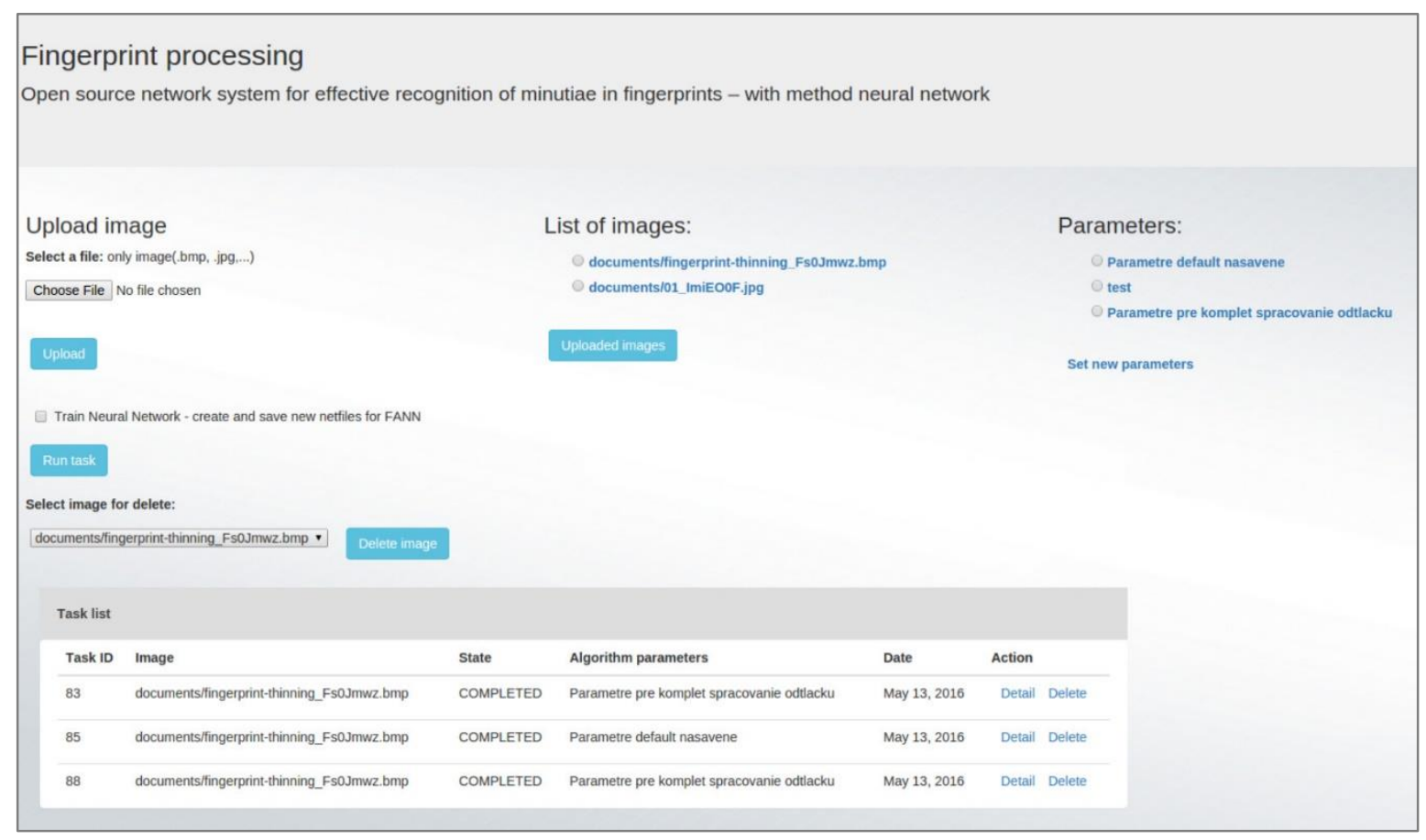

Fig. 5 - Home web page of our server-based application for demonstration of neural networks in automated minutiae detection - version 1.0 (Czakó, 2016)

\section{Software application for mobile devices}

At the time of writing this contribution, the application was available in a version working under Android operating system. Using external Futronic FS80 fingerprint sensor it allows sensing, preprocessing and minutiae extraction. It was tested on our own mobile devices and tablets. It requires a phone/tablet with a OTG-enabled USB port for connecting an external device.

Image capturing process does not take a long time to proceed so the increased power consumption takes equally long. Afterwards we can disconnect the sensor since the processing can be carried out without it. In case of tested devices Huawei, Nexus, HTC, Lenovo, Sony and Toshiba it was not necessary to connect an external power supply. During high intensity usage or using newer devices with lower output current for USB port, the necessity of external power supply is not excluded. FS80 sensor is not FBI-certified product, but it could be replaced by FS88 model meeting FBI specifications.
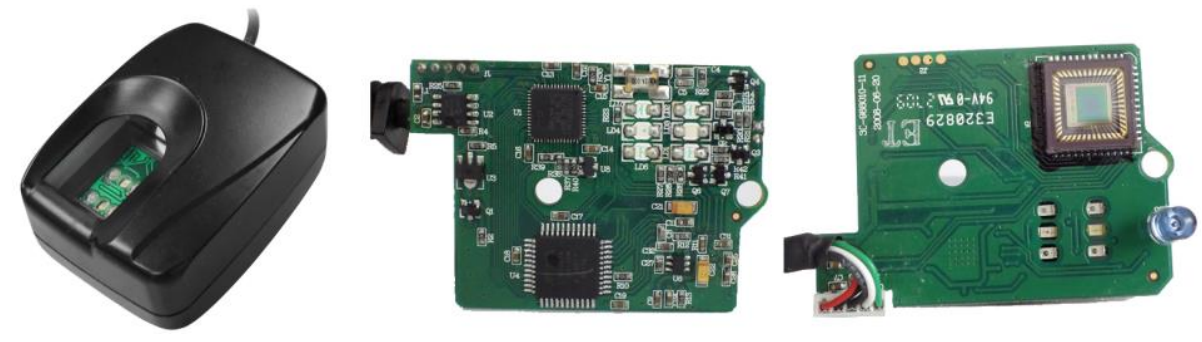

Fig. 6-Futronic FS80 fingerprint scanner

When choosing appropriate fingerprint sensor, we searched for inexpensive and available solution. We were looking for a wide-spread sensor with the ability to store and access image data for further processing. For this reason, most of embedded sensors in mobile devices were not utilizable. FS80 has support for Android operating system. It allows capturing of single fingerprint 
and its consumption does not exceed capabilities of present mobile devices. Our experience indicate the choice was correct. The sensor can be used in authenticating to network part of the system, but because of limited time we did not use this option.

We wanted to achieve full functionality with minimum demands on user. We chose Android operating system to fulfil this. Although we talk about mobile devices, their multi-core processors can handle fingerprint-related computing tasks quite efficiently. Extraction of three most frequent minutiae types was tested. We started to implement extraction of other, more complex minutiae. Since algorithms for their extraction were developed and tested on desktop computers, we do not expect any major difficulties in programming.

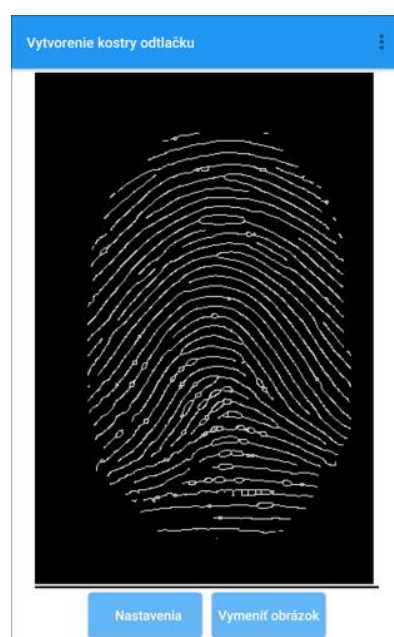

(a)

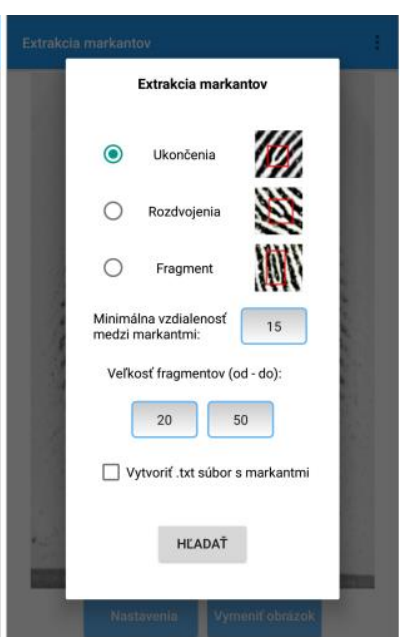

(b)

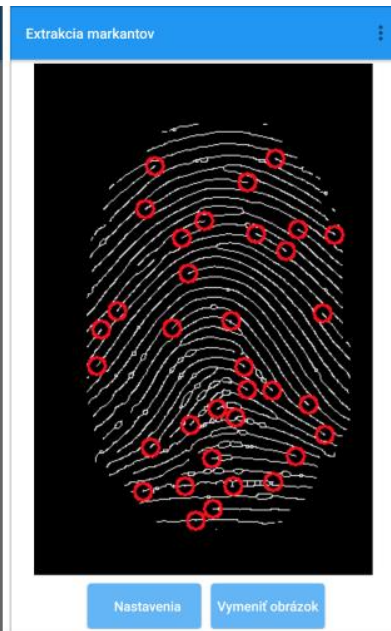

(c)

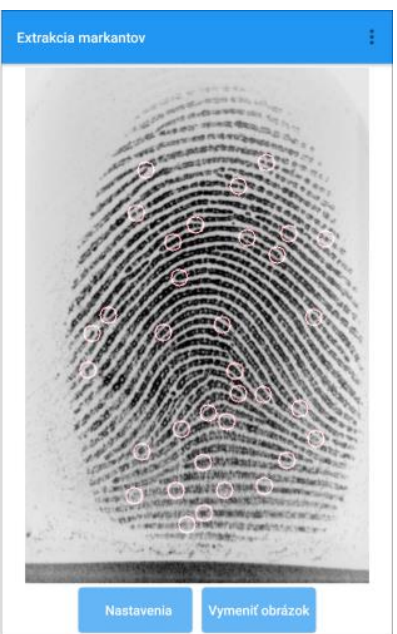

(d)

Fig. 7 - Sample intermediate outputs of fingerprint processing from our mobile Android application (Majzel, 2016)



(a)

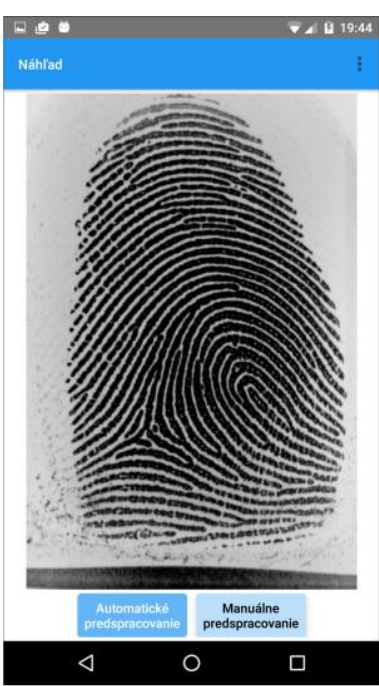

(b)

Fig. 8 - Capturing and storing fingerprint image using our mobile Android application (Majzel, 2016) 


\section{Conclusion}

In this paper we wanted to describe some cardinal problems related to design and implementation of biometric network system and corresponding mobile application. The software was designed to be suitable for teaching Biometrics course laboratory lessons. From what we have learned so far, we may state that our software suite will significantly support the course lessons. It has a potential to train experts and programmers to higher level than ever before. Experience gained from sensing, processing of digital images and their assessment ensure that graduates will have enough skills to design such systems in real world. In case of using our software kit in schools where future forensic experts are trained, it could enhance visualization and reduce time to acquire necessary skills. In further stages, we would like to improve our mobile application by adding support for different operating systems, refine minutiae extraction accuracy and reduce time for batch processing.

The research described in the paper was done within the project No. 1/0529/13 of the Slovak Grant Agency VEGA.

\section{Literature}

1. AMERÍNY, L et. al., A SIFT-based forensic method for copy-move attack detection and transformation recovery. IEEE Transactions on Information Forensics and Security, vol. 6, issue 3, pp. 1099-1110, 2011.

2. LOWE, D. G. Distinctive Image Features from Scale-Invariant Keypoints, Computer Science Department. University of British Columbia, January 5, 2004.

3. TKÁČIK, P. Automatizovaný sietový systém efektívneho rozpoznávania originality obrázkov. [Master thesis - supervised by A. Hambalík], FEI STU Bratislava: Bratislava, 2015.

4. GRZNÁR, M. Biometrické rozpoznávanie identity: odtlačky prstov a algoritmy ich predspracovania. [Bachelor thesis - supervised by P. Marák], FEI STU Bratislava: Bratislava, 2015.

5. HOFERICA, O. Možnosti využitia neurónových sietí v biometrických systémoch pracujúcich $s$ odtlačkami prstov. [Bachelor thesis - supervised by P. Marák], FEI STU Bratislava: Bratislava, 2015.

6. MALTONI, D. et al., Handbook of Fingerprint Recognition: Second Edition. London: Springer, 2009. 496 p. ISBN 978-1-84882-253-5.

7. MAJZEL, M. Android aplikácia pre snímanie a spracovanie odtlačkov prstov pomocou externého snímača [Master thesis - supervised by A. Hambalík], FEI STU Bratislava: Bratislava, 2016.

8. CZAKÓ, G. Sietový systém v otvorenom kóde na efektívne rozpoznávanie markantov $v$ daktyloskopických stopách - pre metódu "neurónové siete" [Master thesis - supervised by A. Hambalík], FEI STU Bratislava : Bratislava, 2016.

9. KOLLMAN, L'. Siet’ový systém v otvorenom kóde na efektívne rozpoznávanie markantov $v$ daktyloskopických stopách [Master thesis - supervised by A. Hambalík], FEI STU Bratislava : Bratislava, 2016.

10. MARÁK, P. - HAMBALÍK, A. Software System for Processing and Analysis of Fingerprints and Determination of Necessary Parameters. Proceedings of the 1st International Conference and Exhibition on Future RFID Technologies, Eger, Hungary, November 5-7, 2014. 


\section{Contact address:}

Alexander Hambalík, Ing. PhD.,

Institute of Computer Science and Mathematics, Faculty of Electrical Engineering and Information Technology, Slovak University of Technology in Bratislava, Ilkovičova 3, 81219 Bratislava, Slovakia, phone: 004212 60291104, e-mail: alexander.hambalik @ stuba.sk

Pavol Marák, Ing.,

Institute of Computer Science and Mathematics, Faculty of Electrical Engineering and Information Technology, Slovak University of Technology in Bratislava, Ilkovičova 3, 81219 Bratislava, Slovakia, phone: 004212 60291597, e-mail: pavol.marak @ stuba.sk 